\title{
屋根型円筒ラチスシェルの自由振動特性の違いが TMD による地震応答低減に与える影響 \\ INFLUENCE OF FREE VIBRATION CHARACTERISTICS OF CYLINDRICAL LATTICE SHELL ROOFS ON SEISMIC RESPONSE REDUCTION BY PLURAL TMDS
}

\author{
熊谷知彦*, 下山拓也**, 小河利行*** \\ Tomohiko KUMAGAI, Takuya SHIMOYAMA and Toshiyuki OGAWA
}

\begin{abstract}
TMD is fit for the vibration control of spatial structure because it is possible to install TMDs by a single supporting point. Therefore, there are many studies on spatial structure with TMD. The authors have verified the influences of the number and position of installed TMDs, the period and phase characteristics of earthquake motions and input directions of input waves on seismic response reduction effects. However, influence of free vibration characteristics of cylindrical lattice shell roofs on vibration control effects by plural TMDs have never been examined. From these backgrounds, the purpose of this study is investigation of seismic response reduction effects by plural TMDs for cylindrical lattice shell roofs which have different half open angles and ratios of natural period of supporting substructure to that of roof structure.
\end{abstract}

Keywords : Cylindrical lattice shell roof, Plural TM Ds, Seismic response reduction, F ree vibration characteristics, Response spectrum analysis, Parallel multi-mass system 屋根型円筒ラチスシェル, 多重 TMD, 地震応答低減, 自由振動特性, 応答スペクトル解析, 並列多質点系

\section{1. 序}

空間構造物は大規模なイベントスペースやスタジアムから小・中 規模な学校体育館などで広く活用されており，大地震や台風などの 災害時には避難所や災害本部などの防災拠点としても利用されるた め, 人命保護と機能維持に対する社会的要求が高い。そのため, 空 間構造物への応答低減機構の適用に関する数多くの研究が行われて いる ${ }^{1)}$ 。これらの研究で用いられる応答低減機構の 1 つとして, 質 量, 復元装置, 減衰装置の 3 要素からなる, パッシブ型の制振装置 である TMD (Tuned Mass Damper) が挙げられる。TMD は構造 物に対して，1 3\% 程度の質量で制振効果を得ることができるとい う利点を有する。また, TMD は 1 つの支点で設置可能であるため, 設置の自由度が高く, 形状が複雑な振動モードが励起される空間構 造物に適した制振装置と考えられる。

空間構造物への TMD の適用に関して, 以下のような研究がなさ れている。アーチ構造物にTMD を適用した研究としては, 薛ら ${ }^{2), 3)}$ が縦方向に振動する TMD を開発し, アーチ模型の振動台実験を行 うことで, 周波数領域と時間領域でその制振効果について考察して いる。吉中ら ${ }^{4), 5)}$ は, 最適条件式 ${ }^{6)-9)}$ を用いて設計した TMD と広 い周期帯を制御可能である MTMD (Multiple TMD) をそれぞれアー チモデルへ適用し，制振効果を分析している。TMDの設計に使用 した最適条件式は定点理論または, 主系に N 個の TMD を設置した
際の応答曲線における, $(\mathrm{N}+1)$ 個の極值のばらつきと極大值を小さ くするという考え方に基づいている。また, 固有周期が近接した複 数のモードが励起される空間構造物に適した TMD の設計法を提案 し，解析的かつ実験的に振動制御の有効性を確認している。津田， 大崎 ${ }^{10)}$ は多方向の振動制御を目的とした TMD をアーチフレーム モデルに適用し，種々の地震動に対する制振効果について解析的に 検討している。著者ら ${ }^{11)}$ は, アーチ構造物を対象として単一のモー ドを制御対象とする最適条件式 ${ }^{6)-9)}$ に基づいた複数個の TMD を設 置し，振動制御を試みている。また，単層ラチスドームに TMD を 適用した研究としては, 以下のものが挙げられる。山田大彦ら ${ }^{12)}$ 14) は, 単層ラチスドームを対象として, 複数の TMDを設置し, TMD の設置位置および設置数, 動作方向, ドームの 1 次固有振動 数に対する TMD の固有振動数の比をパラメーターとして, 制振効 果を解析的に検討している。吉中ら ${ }^{15), 16)}$ は，スパン $60 \mathrm{~m}$ の中規 模単層ラチスドームに MTMD を適用し, MTMD 設置後のモード 形状の変化に対応することが可能な新たな MTMD の設置方法を提 案し, その有効性を確認している。また, 屋根型円筒ラチスシェ ルにTMDを適用した研究としては, 以下のものが挙げられる。吉 中ら ${ }^{17)}$ は, 単層円筒ラチスモデルに MTMD を分散配置した場合 に，構造物全体の応答を制御可能であることを確認している。著 者ら ${ }^{18), 19)}$ は, 屋根型円筒ラチスシェルに最適条件式 ${ }^{6)-9)}$ に基づい

\footnotetext{
* 明治大学理工学部建築学科 准教授 ·博士 (工学)

** ジェイアール東日本建築設計事務所 修士 (工学) (元明治大学大学院 大学院生)

*** 東京工業大学 名誉教授·工博
}

Assoc. Prof., Dept. of Arch., School of Science and Technology, Meiji University, Dr. Eng. JR East Design Corporation, M. Eng. (Former Grad. Student, Meiji University)

Prof. Emeritus, Tokyo Institute of Technology, Dr. Eng 
たTMD を設置し，複数のモードの制御を試みている。その結果， TMD の設置位置および設置数, 入力地震波の周期・位相特性, 入 力方向の違いが応答低減効果に与える影響を明らかにしている。さ らに，並列多質点系を用いて，屋根型円筒ラチスシェルにTMDを 適用した場合の応答低減率をエネルギー吸収率との関係から評価す る方法を提案している。このように，空間構造物に適した TMDの 設計方法, 設置位置, 設置数などについての研究は意欲的に行われ ている。一方で, 空間構造物の振動特性は構造物のスパン, ライズ, 屋根構造と下部構造における構造特性の関係などにより大きく変化 するため 20)-25)，空間構造物への TMD の適用に関する研究におい ては，構造物の形状や構造特性に応じた分析が必要である。しかし ながら，制御対象とする空間構造物の形状や構造特性が異なること により変化する自由振動特性に着目し, TMD の制振効果について 論じた研究は見当たらない。

そこで本研究では, 屋根型円筒ラチスシェルを対象として, 水平 方向入力に対して励起される鉛直応答を TMDにより制振する場合 に, 半開角および屋根構造と下部構造の固有周期比が異なることに より変化する自由振動特性が TMD の応答低減効果に与える影響を 分析する。半開角を変化させることで, 文献 22) で確認されている 半開角が大きくなるにつれて屋根構造の鉛直応答が大きくなるとい う特性が，TMDの応答低減効果に与える影響を分析する。なお, 本研究では構造物の応答が弾性範囲内であるときに TMD を適用し た際の制振効果を検討する。まず，地震応答を制御する場合に適し た，TMDにより制御対象とするモードの選択方法を提案する。次 に, 自由振動特性が異なる屋根型円筒ラチスシェルに TMD を設置 することによる, 最大鉛直応答, および全節点の全解析ステップに おける鉛直応答の二乗值の総和の平方根の低減効果を分析寸る。さ らに，屋根構造と下部構造の固有周期比と TMD による応答低減率 の関係から, TMD による応答低減効果が高い固有周期比の範囲に ついて検討する。最後に, TMD を設置した屋根型円筒ラチスシェ ルを並列多質点系に置換することで，TMDによる最大鉛直応答お よび全節点の全解析ステップにおける鉛直応答の二乗值の総和の平 方根の低減率の評価を試みる。

\section{2. 屋根型円筒ラチスシェルの数值解析概要}

\section{2-1. 解析モデル}

図 1 に解析モデルの形状, 表 1 に形状諸元および総質量, 表 2 に部材諸元を示す。対象構造物は, 学校体育館規模の屋根型円筒 ラチスシェルとする。境界条件は柱脚部で固定とし，屋根構造と 下部構造は剛に接合されている。屋根架構の半開角 $\theta$ は 20,30 , 40deg. の 3 種類, 屋根構造と下部構造の曲げ剛性はそれぞれ下記 の設計を行ったモデルを基準に 1 倍，10 倍，100 倍に変化させる。 なお，部材断面積は変化させない。屋根構造の剛性が 10 倍，100 倍のモデルは表 3 に示したデプス $d$ / スパン $\mathrm{L}_{x}$ 比程度の二層円筒ラ チスシェルに相当する。モデル名は $\mathrm{F} \theta(20,30,40)$ - 屋根構造の 剛性倍率（1，10，100）－下部構造の剛性倍率（1，10，100）と する。モデルを構成する部材は全て円形鋼管とする。基準となる曲 げ剛性が 1 倍のモデルにおける部材設計は, ラチス材, 境界部材（妻 面アーチ, 妻面梁, 桁行梁, 束材) で構成される屋根構造と, 柱, 梁（妻面梁，桁行梁）で構成される下部構造に分けて行う。屋根構
造は, 固定荷重に対して, 鋼構造設計規準 ${ }^{26)}$ における部材安全率 $v=2.5$ とした短期許容応力度設計により, 部材安全率がほぼ一様 となるように部材断面を決定する。なお，鋼材のヤング係数 $\mathrm{E}$ は $206000 \mathrm{~N} / \mathrm{mm}^{2}, \mathrm{~F}$ 值は $235 \mathrm{~N} / \mathrm{mm}^{2}$ とする。また, 基準となる曲げ 剛性が 1 倍のモデルに対しては, 文献 27) に従い, 全体座屈耐力の 検定を行い自重に対する安全性を確認している。下部構造は, ベー スシア係数 $\mathrm{C}_{0}=0.3$ のせん断力および固定荷重に対して, 弾性範囲 であるように設計する。固定荷重は, 屋根構造 $1.18 \mathrm{kN} / \mathrm{m}^{2}$, 下部構 造 $0.98 \mathrm{kN} / \mathrm{m}^{2}$ とし, 固定荷重に相当する質量を, 各節点に集中質 量として与える。なお，本論文中では図 1 に示寸節点名を用いる。

\section{2-2. 解析方法}

解析方法は, 線形固有值解析, 応答スペクトル解析, 幾何学的非 線形性を考慮した動的弾性応答解析である。応答スペクトル解析は 式 (1)，（2）を用いて行う。

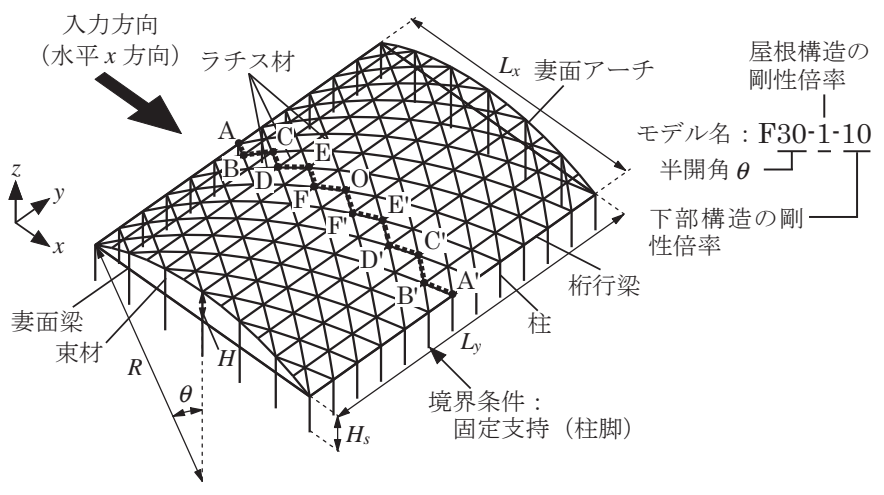

図 1 対象構造物（屋根型円筒ラチスシェル）

表 1 形状諸元および総質量

\begin{tabular}{|c||c|c|c|}
\hline 半開角 $\theta$ [deg.] & 20 & 30 & 40 \\
\hline \hline $\mathrm{x}$ 方向スパン $\mathrm{L}_{\mathrm{x}}[\mathrm{m}]$ & \multicolumn{3}{|c|}{36} \\
\hline $\mathrm{y}$ 方向スパン $\mathrm{L}_{\mathrm{y}}[\mathrm{m}]$ & 53 & 38 & 28 \\
\hline 曲率半径 $\mathrm{R}[\mathrm{m}]$ & 3.17 & 4.82 & 6.55 \\
\hline ライズ $\mathrm{H}[\mathrm{m}]$ & \multicolumn{4}{|c|}{} \\
\hline 支持柱長さ $\mathrm{H}_{\mathrm{s}}[\mathrm{m}]$ & 277 & 290 & 307 \\
\hline 総質量 $\mathrm{M}_{0}[\mathrm{t}]$ & \multicolumn{3}{|c}{} \\
\hline \multicolumn{1}{|||}{}
\end{tabular}

表 2 部材諸元

\begin{tabular}{|c|c|c|c|c|c|c|}
\hline & \begin{tabular}{|l||} 
半開角 \\
$\theta$ [deg.] \\
\end{tabular} & $\begin{array}{c}\text { 部材細長比 } \\
\lambda\end{array}$ & $\mid \begin{array}{c}\text { 外径 } \\
D[\mathrm{~cm}]\end{array}$ & $\begin{array}{l}\text { 厚さ } \\
\mathrm{t}[\mathrm{cm}]\end{array}$ & $\begin{array}{l}\text { 断面積 } \\
\text { A }\left[\mathrm{cm}^{2}\right]\end{array}$ & $\begin{array}{c}\text { 断面二次 } \\
\text { モーメント } \\
\text { I [ }\left[\mathrm{cm}^{4}\right]\end{array}$ \\
\hline \multirow{3}{*}{ ラチス材 } & 20 & $18.0 \sim 33.3$ & 31.85 & $0.35,0.55,0.80$ & $34.6,54.1,78.0$ & $4296,6625,9411$ \\
\hline & 30 & $26.6 \sim 50.9$ & 21.63 & $0.35,0.55,0.95$ & $23.4,36.4,61.7$ & $1325,2025,3306$ \\
\hline & 40 & $34.4 \sim 68.8$ & 16.83 & $0.40,0.70,1.15$ & $20.6,35.5,56.6$ & $697,1156,1750$ \\
\hline \multicolumn{2}{|c|}{ 妻面アーチ } & $17.4 \sim 18.5$ & 50.80 & \begin{tabular}{|l|}
1.00 \\
\end{tabular} & \begin{tabular}{|l|}
156.5 \\
\end{tabular} & 48520 \\
\hline \multicolumn{2}{|c|}{ 妻面梁 } & $41.9 \sim 46.2$ & 40.64 & 1.10 & 136.6 & 26724 \\
\hline \multicolumn{2}{|c|}{ 桁行梁 } & 28.4 & 40.64 & 0.80 & 100.1 & 19874 \\
\hline \multicolumn{2}{|c|}{ 束材 } & $26.6 \sim 99.2$ & 19.07 & 0.40 & 23.5 & 1023 \\
\hline \multicolumn{2}{|c|}{ 柱 } & 34.0 & 50.8 & 0.85 & 133.4 & 41611 \\
\hline
\end{tabular}

※ヤング係数 E は全ての部材において $206000\left[\mathrm{~N} / \mathrm{mm}^{2}\right]$ とする。

表 3 デプス/スパン比 $\left(d / L_{x}\right)$

\begin{tabular}{|c||c|c|c|}
\hline \multirow{2}{*}{ 半開角 $\theta$ [deg.] } & \multicolumn{3}{|c|}{ 屋根の面外剛性 } \\
\cline { 2 - 4 } & 1 倍 & 10 倍 & 100 倍 \\
\hline \hline 20 & - & $1 / 52$ & $1 / 16$ \\
\hline 30 & - & $1 / 77$ & $1 / 24$ \\
\hline 40 & - & $1 / 101$ & $1 / 32$ \\
\hline
\end{tabular}




$$
\begin{aligned}
& { }_{k} A_{j}^{V}=\left|{ }_{k} \beta \cdot{ }_{k} \mathrm{u}_{j}^{V} \cdot{ }_{k} \mathrm{~S}_{\mathrm{A}}\right| \\
& { }_{k} D_{j}^{V}=\left|{ }_{k} \beta \cdot{ }_{k} u_{j}^{V} \cdot{ }_{k} S_{D}\right|
\end{aligned}
$$

ここに, $k A_{j}^{V}, k D_{j}^{V}$ は $k$ 次モードの j 節点における最大鉛直応答加速 度, 最大鉛直応答変位, $\mathrm{k} \beta$ は $\mathrm{k}$ 次モードの刺激係数, $\mathrm{k} \mathrm{Uj}_{\mathrm{j}}^{\mathrm{V}}$ は $\mathrm{k}$ 次モー ドの j 節点における固有ベクトルの鉛直方向成分, ${ }_{k} S_{A},{ }_{k} S_{D}$ は $k$ 次モー ドの固有周期における加速度応答スペクトル, 変位応答スペクトル の值である。

動的弾性応答解析には数值積分法として Newmark $\beta$ 法 $(\beta=1 / 4)$

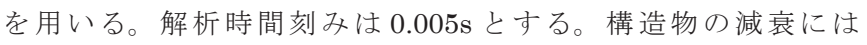
Rayleigh 型を用いる。荷重入力は， $t=0.0 \sim 1.0 \mathrm{~s}$ の間で固定荷重を 加え, その後 $\mathrm{t}=1.0 \sim 4.0 \mathrm{~s}$ の間で荷重を固定し, 静的釣合を得た後, $\mathrm{t}=4.0 \mathrm{~s}$ 以降で動的荷重を加える方法により行う。その際の減衰定 数 $\mathrm{h}$ は, $\mathrm{t}=0.0 \sim 4.0 \mathrm{~s}$ では固定荷重を加えた後の静的釣合を得るた めに 100\%（臨界減衰）とし, 動的荷重を加える $\mathrm{t}=4.0 \mathrm{~s}$ 以降では 一般的な鉄骨構造の減衰に Rayleigh 型を用いる場合に設定する 1 次と 2 次のモードに対し $2 \%$ とする。

\section{2-3. 入力波}

入力地震波は図 1 に示すように水平 $\mathrm{x}$ 方向に入力する。地震 波は，観測地震波である El Centro NS(1940)，Taft EW(1952), Hachinohe NS(1968)，JMA Kobe NS(1995) に観測地震波の位相特 性を採用した模擬地震波の 4 波を加え, 計 8 波とする。模擬地震 波は告示 1461 号（国交省）で規定される I 種地盤用の増幅係数に 基づき, 告示 1457 号（国交省）で規定される表層地盤の増幅特性 を考慮し作成する。本研究では， 1 次モードと 2 次モードに対して $h=0.02$ の減衰を有する鋼構造骨組を対象とするため, 減衰に伴う 加速度の低減率を考慮し, 加速度応答スペクトルを修正する。修正 した目標加速度応答スペクトルを表 4 に表す。観測地震波の最大入 力加速度 $A_{g}$ は $100 \mathrm{~cm} / \mathrm{s}^{2}$ に基準化する。図 2 に本研究の入力地震波 の加速度応答スペクトルを示す。 $S_{A}$ は加速度応答スペクトルの值 である。

表 4 目標加速度応答スペクトル $(h=0.02)$

\begin{tabular}{|c||c|c|c|}
\hline 周期 $\mathrm{T}[\mathrm{s}]$ & $\mathrm{T} \leqq 0.16$ & $0.16 \leqq \mathrm{~T} \leqq 0.864$ & $0.864 \leqq \mathrm{~T}$ \\
\hline 加速度 $\left[\mathrm{cm} / \mathrm{s}^{2}\right]$ & $120+1125 \mathrm{~T}$ & 300 & $259 / \mathrm{T}$ \\
\hline
\end{tabular}

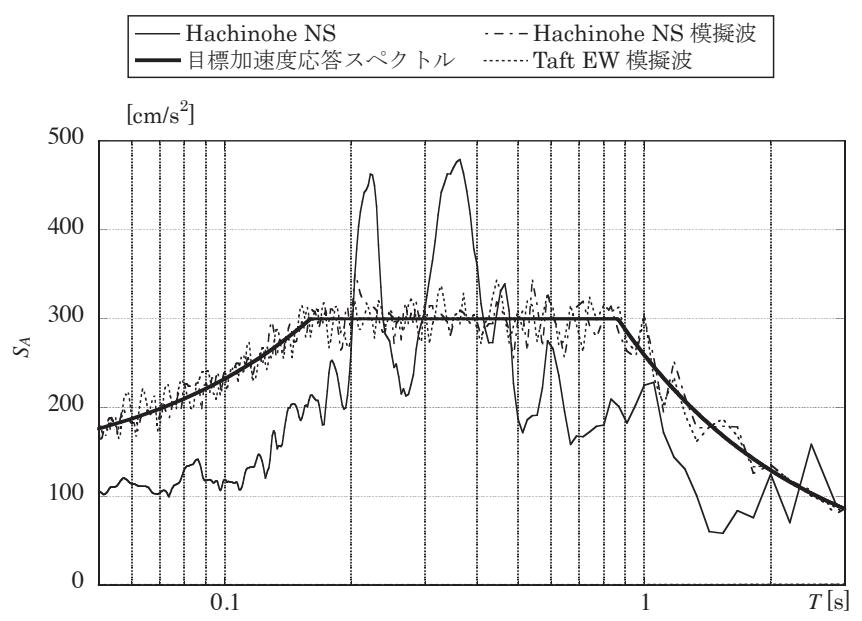

図 2 入力地震波の加速度応答スペクトル

\section{TMDによる制御対象モードの選択方法}

線形固有值解析および応答スペクトル解析により, TMD を用い て制御するモード（以下，制御対象モードと呼ぶ）を決定する。空 間構造物は高次のモードを含む複数のモードの有効質量比が大きく なる特性を有する。既往の研究では有効質量比の大きなモードを制 御対象モードとする場合が多く見られるが，有効質量比の大きな高 次のモードを制御対象とすると, 応答加速度は大きいものの, 応答 変位が低次モードに比べて小さくなる。そのため, 構造物の応答変 位に対するTMDの相対変位が小さくなり, 応答低減効果が低くく なることを確認している。このような TMD の特徵を踏まえて, 文 献 18) では，加速度応答スペクトルを一定 $\left(1.0 \mathrm{~cm} / \mathrm{s}^{2}\right)$ としたとき の式 (2) による略算值である最大鉛直応答変位の值が大きいモード を制御対象とした。しかし, 地震応答を制御する場合には地震波の 応答スペクトルを考慮した制御対象モードの選択方法が適している と考えられる。また, 1 つの節点の最大応答だけでなく, 構造物全 体の応答から制御対象モードを選択する必要がある。そこで, 本研 究では地震波の応答スペクトルを考慮した新たな制御対象モードの 選択方法を提案する。提案する制御対象モードの選択手順は次の通 りである。

1）式（2）および表 4, 図 2 に示した告示第 1457,1461 号に基づい た加速度応答スペクトルを用いて応答スペクトル解析を行い, 各 モードの全節点数 $N_{j}$ の最大鉛直応答変位の和 $\sum_{k=1}^{N} k D_{j}^{V}$ を略算する。

2) 有効質量比の合計が $99 \%$ に達するモード次数 N ${ }^{\mathrm{em}}$ までの各モー ドの全節点の最大鉛直応答变位の和の合計 $\sum_{k=1}^{N e n=1} \sum_{1}^{N} D_{j}^{V}$ 算出する。

3）手順 1)，2）で算出した值を式 (3) に代入し，K 次モードの最大鉛 直応答変位の割合 ${ }_{k} R_{D}^{V}$ を算出する。本研究では, ${ }_{k} R_{D}^{V}$ が $10 \%$ よ り大きいモードを制御対象とする。

$$
{ }_{K} R_{D}^{V}=\sum_{j=1}^{N_{J}}{ }_{K} D_{j}^{V} / \sum_{k=1}^{N^{e m}} \sum_{j=1}^{N_{J}}{ }_{k} D_{j}^{V}
$$

表 5 および図 3 に提案した方法に従い選択した $\mathrm{F} *-1-1$ （*は 20, 30, 40), F20-100-1, F30-*-1, F30-1-*（* は 10, 100) の制御対象モードを示す。表 5 中には各モデルの制御対象モードの 自由振動特性，式 (3) で算出した最大鉛直応答变位の割合 ${ }_{k} R R_{D}^{V}$ お び式 (4) を用いて算出した最大鉛直応答加速度の割合 $k R_{A}^{V}$, 全制御 対象モードにおける最大鉛直応答加速度, 変位の割合の合計を示す。

$$
{ }_{K} R_{A}^{V}=\sum_{j=1}^{N_{J}}{ }_{K} A_{j}^{V} / \sum_{k=1}^{N^{e m}} \sum_{j=1}^{N_{J}} A_{j}^{V}
$$

有効質量比が大きくとも, $\mathrm{K}_{\mathrm{D}}^{V}$ が大きくなるとは限らないことがわ かる。また, 全制御対象モードにおける最大鉛直応答の割合の合計 が大きいモデルの応答低減効果は高くなることが予想される。各モ デルの全制御対象モードにおける最大鉛直応答変位の割合の合計は $70 \%$ 以上となっている。半開角が異なる F20-1-1, F30-1-1，F401-1 を比較すると, F20-1-1 は F30-1-1, F40-1-1 に比べて最大鉛直 変位の割合が大きいモードの数が少なくなっており, 振動の腹の数 が 2 つであり形状が単純なモードが卓越する。屋根構造の剛性比が 異なる F30-*-1（*は 1, 10, 100）を比較すると, 屋根構造の 剛性が大きくなるにつれて, 逆対称 1 波モードの有効質量比および ${ }_{k} R_{A}^{V}, \quad K R_{D}^{V}$ が大きくなり, モード形状が単純化される。F30-100-1で は屋根構造が逆対称 1 波モードかつ下部構造がスウェイするモード が励起される。なお, 半開角が小さい F20-100-1 では屋根構造がほ 
表 5 各モデルの制御対象モード

(i) $\mathrm{F} *-1-1 （ *$ は $20,30,40)$

\begin{tabular}{|c|c|c|c|c|c|c|c|c|}
\hline モデル名 & \multicolumn{2}{|c|}{ F20-1-1 } & \multicolumn{3}{|c|}{ F30-1-1 } & \multicolumn{3}{|c|}{ F40-1-1 } \\
\hline モード次数 & 1 次 & 4 次 & 1次: & 4 次 & 7 次 & 1 次 & 3 次 & 7 次 \\
\hline モードの腹の数 & 2 & 2 & 2 & 4 & 4 & 2 & 4 & 4 \\
\hline 固有周期 T [s] & 0.642 & 0.356 & 0.958 & 0.456 & 0.356 & 1.031 & 0.607 & 0.388 \\
\hline 減衰定数 h [\%] & 2.00 & 2.32 & $2.00 \vdots$ & 2.33 & 2.82 & 2.00 & 2.22 & 2.89 \\
\hline 有効質量比 [\%] & 12.5 & 77.8 & 5.8 & 43.1 & 45.6 & 4.9 & 21.4 & 58.2 \\
\hline 有効質量比の合計 [\%] & \multicolumn{2}{|c|}{90.3} & \multicolumn{3}{|c|}{94.5} & \multicolumn{3}{|c|}{84.5} \\
\hline $\begin{array}{c}\text { 最大鉛直応答加速度の割合 } \\
{ } R_{A}^{V}[\%]\end{array}$ & 26.9 & 30.2 & 13.3 & 33.0 & 27.7 & 9.6 & 24.2 & 25.3 \\
\hline $\begin{array}{c}\text { 最大鉛直応答加速度 } \\
\text { の割合の合計 [\%] }\end{array}$ & \multicolumn{2}{|c|}{57.1} & \multicolumn{3}{|c|}{74.1} & \multicolumn{3}{|c|}{59.1} \\
\hline $\begin{array}{c}\text { 最大鉛直応答変位の割合 } \\
{ } R_{D}^{V}[\%] \\
\end{array}$ & 66.0 & 22.9 & 51.8 & 29.1 & 13.3 & 39.2 & 34.2 & 14.6 \\
\hline $\begin{array}{c}\text { 最大鉛直応答変位 } \\
\text { の割合の合計 [\%] }\end{array}$ & \multicolumn{2}{|c|}{88.9} & \multicolumn{3}{|c|}{94.2} & \multicolumn{3}{|c|}{87.9} \\
\hline
\end{tabular}

(ii) F30-1-*, F30-*-1（*は 10, 100)

\begin{tabular}{|c|c|c|c|c|}
\hline モデル名 & F30-10-1 & F30-100-1 & F30-1-10 & F30-1-100 \\
\hline モード次数 & 1 次: 3 次 & 1 次: 5 次 & 1 次: 5 次 & 1 次： \\
\hline モードの腹の数 & $\begin{array}{|l:l|}2 & 2 \\
\end{array}$ & $\begin{array}{|l:l|}2 & 2 \\
\end{array}$ & $\begin{array}{|l:l|}2 & 4 \\
\end{array}$ & $\begin{array}{|l:l|}2 & 4 \\
\end{array}$ \\
\hline 固有周期 T [s] & $\begin{array}{|l:l|}0.431 & 0.269 \\
\end{array}$ & $0.291: 0.130$ & \begin{tabular}{|l:l}
0.820 & 0.400 \\
\end{tabular} & \begin{tabular}{|l:l}
0.711 & 0.388 \\
\end{tabular} \\
\hline 減衰定数 h [\%] & $\begin{array}{ll:l}2.00 & 2.18 \\
\end{array}$ & $\begin{array}{|l:l|}2.00 & 2.47 \\
\end{array}$ & $\begin{array}{|l:l|}2.00 & 2.40 \\
\end{array}$ & $\begin{array}{|l:l|}2.00 & 2.35 \\
\end{array}$ \\
\hline 有効質量比 [\%] & $\begin{array}{l:l}51.1 & 45.5 \\
\end{array}$ & $\begin{array}{l:l}96.4 & 3.5 \\
\end{array}$ & $\begin{array}{l:l}4.4 & 6.1 \\
\end{array}$ & $\begin{array}{l:l}4.3 & 5.3 \\
\end{array}$ \\
\hline 有効質量比の合計 [\%] & 96.6 & 99.9 & 10.5 & 9.6 \\
\hline $\begin{array}{c}\text { 最大鉛直応答加速度の割合 } \\
\operatorname{kRA} R_{A}^{Y}[\%]\end{array}$ & $\begin{array}{l:ll}44.5 & 38.8\end{array}$ & $\begin{array}{l:l}53.8 & 46.2\end{array}$ & 8.5 & $\begin{array}{l:l}9.4 & 11.1\end{array}$ \\
\hline $\begin{array}{c}\text { 最大鉛直応答加速度 } \\
\text { の割合の合計 [\%] }\end{array}$ & 83.3 & 100 & 15.4 & 20.5 \\
\hline $\begin{array}{c}\text { 最大鉛直応答変位の割合 } \\
{ }_{k} R_{D} \text { [\%] }\end{array}$ & $\begin{array}{ll:l}72.5 & 24.6\end{array}$ & $\begin{array}{l:l}85.4 & 14.6\end{array}$ & $\begin{array}{l:l}56.5 & 16.5\end{array}$ & $62.1 \vdots$ \\
\hline $\begin{array}{l}\text { 最大鉛直応答変位 } \\
\text { の割合の合計 [\%] }\end{array}$ & 97.1 & 100 & 73.0 & 83.9 \\
\hline
\end{tabular}

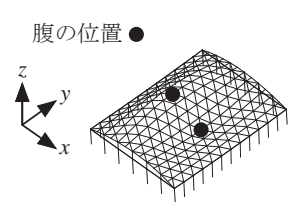

(a) 1 次モード

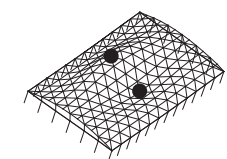

(b) 4 次モード

(i) $\mathrm{F} 20-1-1$

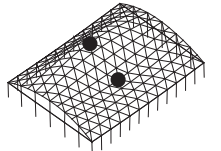

(a) 1 次モード

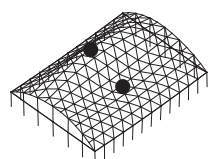

(a) 1 次モード

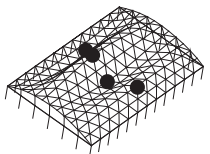

(b) 4 次モード

(iii) F30-1-1

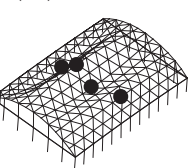

(b) 3 次モード

(iv) $\mathrm{F} 40^{-1-1}$

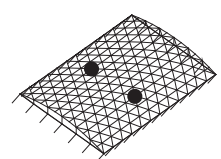

1 次モード

(ii) F20-100-1

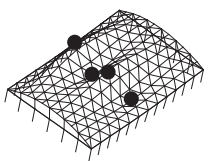

(c) 7 次モード

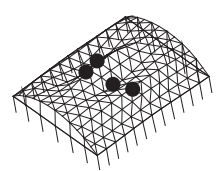

(c) 7 次モード

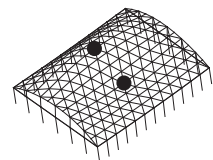

(a) 1 次モード

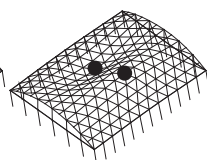

(b) 3 次モード

(v) F30-10-1

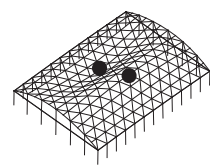

(a) 1 次モード

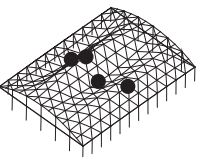

(vii) F30-1-10

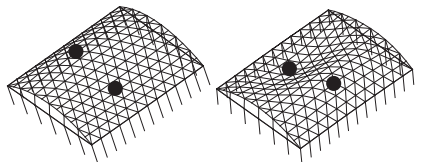

(a) 1 次モード（b) 5 次モード (vi) F30-100-1

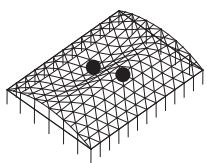

(a) 1 次モード (b) 5 次モード (viii) F30-1-100
図 3 制御対象モードの形状
とんど振動せず，下部構造がスウェイするモードが卓越する。下部 構造の剛性比が異なる F30-1- *（*は 1，10，100）を比較すると， F30-1-1 に比べて F30-1-10，F30-1-100 の有効質量比および全制御 対象モードにおける最大鉛直応答加速度の割合の合計は小さくな る。これは, ${ }_{k} R_{D}^{V}$ が小さい高次のモードが卓越しているためである。

\section{TMD の設計および設置方法}

各 TMDの同調比および減衰比の算出方法について説明する。本 研究では，TMDの設置数を 2 個とする二重 TMD，4 個とする四重 $\mathrm{TMD}$ を対象とし, それぞれ異なる最適条件式を用いて設計する。式 （5）～(7) に TMD の質量比, 同調比, 減衰比を示す。

質量比 : $\mu_{N}=\frac{m_{T}}{M_{j k}}$

同調比 : $\gamma_{N}^{(n)}=\frac{\omega_{0}}{\omega_{T}}=\frac{T_{T}}{T_{0}}$

減衰比: $\zeta_{N}^{(n)}=\frac{c_{T} T_{T}}{4 m_{T} \pi}$

ここに，nはTMDの固有周期が長い順に並べたときの順番，N は $\mathrm{TMD}$ の設置個数, $\mathrm{m}_{\mathrm{T}}$ は TMD の 1 個当たりの質量, $M_{\mathrm{jk}}$ はモード の最大振幅点の等価質量, $\mathrm{T}_{\mathrm{T}}$ は TMD の固有周期, $\mathrm{T}_{0}$ は制御対象 とするモードの固有周期，CT は TMD の減衰係数である。

多自由度系モデルの TMD の設計においては, 主系の質量には等 価質量を用いる方法が一般的である ${ }^{28)}$ 。そこで本研究では, 質量比 の算定には等価質量 $M_{j k}$ を用いる。ここに，j は節点番号， $k$ はモー ド次数である。文献 28) では, 複数の TMD を同一の節点に設置し, 設置点の等価質量を用いて TMD の質量比を算出しており，全ての TMD の質量比は同じ值を用いている。しかし, 複数の TMD を異 なる節点に分散設置した場合にどのように等価質量を設定するか は提案されていない。本研究では, 複数の TMD を異なる節点に分 散設置するが，全ての TMDの質量比を統一するため，等価質量は TMD の設置位置によらず, 各モードの固有ベクトルの鈶直方向成 分の最大值を 1 としたときの固有ベクトルが最大の節点における值 とする。TMDの同調比および減衰比は, 既往の研究で示されてい る最適条件式である式 $(8)$ ～(11) を用いて算出する。二重 TMD で は定点理論に基づく最適条件式 ${ }^{8)}$ を用いる。四重 TMD では, 主系 に N 個の TMD を設置した際の忘答曲線における, $(\mathrm{N}+1)$ 個の極值の ばらつきと極大值を小さくするという考え方に基づいた最適条件式 ${ }^{9)}$ を用いる。二重 TMD, 四重 TMD では同調比の算出に式 (8) および 表 6 , 減衰比の算出に式 (11) および表 7 をそれぞれ用いる。ただし, 二重 TMD の 2 番目の TMD の同調比には式 (9), 四重 TMD の 4 番 目の TMD の同調比は式 (10) を用いる。

\section{【同調比】}

-二重 TMD, 四重 TMD

$$
\frac{1}{\gamma_{N}^{(n)}}=a\left(\mu_{N}+b\right)^{c}
$$

表 6 一般式（同調比）の係数

\begin{tabular}{|c|c||c|c|c|}
\hline \multicolumn{2}{|c||}{} & $\mathrm{a}$ & $\mathrm{b}$ & $\mathrm{c}$ \\
\hline \hline 二重 TMD & $\gamma_{2}^{(1)}$ & 0.4032 & 0.1300 & -0.4340 \\
\hline & $\gamma_{4}^{(1)}$ & 0.2193 & 0.0699 & -0.5487 \\
\multirow{3}{*}{ 四重 TMD } & $\gamma_{4}^{(2)}$ & 0.2721 & 0.1301 & -0.6289 \\
& $\gamma_{4}^{(3)}$ & 0.7697 & 0.8667 & -1.9992 \\
\hline
\end{tabular}


• 二重 $\mathrm{TMD}$ の 2 番目の TMD

$\frac{1}{\gamma_{2}^{(2)}}=-0.72 \mu_{2}+1.04$

・四重 TMD の 4 番目の TMD

$$
\frac{1}{\gamma_{4}^{(4)}}=1.1327 \exp \left(-0.9314 \mu_{4}\right)-0.0953 \exp \left(-72.417 \mu_{4}\right)
$$

【減衰比】

-二重 TMD, 四重 TMD

$$
\zeta_{N}^{(n)}=\left(d \mu_{N}\right)^{e}-f
$$

表 7 一般式（減衰比）の係数

\begin{tabular}{|c|c||c|c|c|}
\hline \multicolumn{2}{|c|}{} & $\mathrm{d}$ & $\mathrm{e}$ & $\mathrm{f}$ \\
\hline \hline \multirow{2}{*}{ 二重 TMD } & $\zeta_{2}^{(1)}$ & 0.0222 & 0.0700 & 0.5050 \\
& $-\zeta_{2}^{(2)}$ & 0.2000 & 0.3770 & 0.0380 \\
\hline \multirow{3}{*}{ 四重 TMD } & $\zeta_{4}^{(1)}$ & $1.3066 \times 10^{-4}$ & 0.0772 & 0.3040 \\
& $-\zeta_{4}^{(2)}$ & $1.9270 \times 10^{-3}$ & 0.1355 & 0.1786 \\
& $-\bar{\zeta}_{4}^{(3)}$ & $2.9512 \times 10^{-2}$ & 0.2405 & 0.0883 \\
& $-\zeta_{4}^{(4)}$ & 0.2877 & 0.4319 & 0.0248 \\
\hline
\end{tabular}

表 8 に TMD の設計值を示す。モードの腹の数が 2 つのモードに は二重 TMD，4つのモードには四重 TMD を適用する。TMD の質 量は各モードの等価質量 $M_{j k}$ に対する各モードを制御する TMD の 合計質量 $\mathrm{m}_{\mathrm{T}} \times \mathrm{N}$ の比が $6 \%$ となるように設定する。なお，各モデ ルに設置する TMDの総質量はシェル構造物の総質量 $M_{0}$ の 1 ～ $3 \%$ となる。本研究で適用する TMD の質量の設定方法では, 制御対象 モードの数が少なくなるほど，構造物の総質量に対する TMDの総 質量の比が小さくなるため, 構造物への負担およびコストが低減 する。図 4 に各モデルの TMD の設置位置を示す。TMD の設置位 置は文献 18),19）により構造物全体の応答の低減が確認されている モードの全ての振動の腹とする。モードの振動の腹は図 3 に示した ように $\mathrm{AOA}^{\prime}$ 上に位置している。周期の長い TMD から順に, A か ら $\mathrm{A}^{\prime}$ 点に向かって分散して設置する。本研究では，水平方向入力 に対して励起される鉛直応答の制振を行うことを目的としているた め，設置方向は鈶直下向きとし，振動方向は鉛直方向のみとする。 解析では TMD を 1 方向バネでモデル化し，実際に TMD を製作す る際には，ガイドにベアリングを使用して，水平方向の振動を拘束 する等が考えられる。

\section{TMDによる地震応答の低減効果}

本章では，屋根型円筒ラチスシェルの自由振動特性および応答ス ペクトル解析により略算した全制御対象モードにおける最大鉛直応 答の割合の合計と TMD による地震応答の低減効果の関係について 分析する。さらに, 屋根構造と下部構造の固有周期比と応答低減率 の関係から TMD による応答低減効果が高い固有周期比の範囲につ いて検討する。

\section{5-1. 最大鉛直応答の低減効果}

図 5 に F *-1-1（*は20，30，40）拈よび F30-*-1，F30-1-* （*は10,100）の Hachinohe NS 模擬波に対する $\mathrm{AOA}^{\prime}$ 上の最大鉛 直応答加速度倍率 $A_{r}^{V} / A_{g}$, 最大水平応答加速度倍率 $A_{r}^{H} / A_{g}$ を示す。表 5 および図 3 に示したように,F20-1-1, F30-10-1, F30-100-1 は逆 対称 1 波のモードのみが卓越し，F30-1-1，F30-1-10，F30-1-100，

\begin{tabular}{|c|c|c|c|c|c|c|}
\hline モデル名 & TMD 名 & $\begin{array}{c}\text { 主系の } \\
\text { 等価質量 } \\
M_{\mathrm{jk}}[\mathrm{kg}]\end{array}$ & $\begin{array}{c}\text { TMD } \\
\text { の質量 } \\
\text { mT }[\mathrm{kg}]\end{array}$ & $\begin{array}{c}\text { TMD } の \\
\text { 固有周期 } \\
\mathrm{T}_{\mathrm{T}}[\mathrm{s}]\end{array}$ & $\begin{array}{c}\text { 主系の } \\
\text { 固有周期 } \\
\mathrm{T}_{0}[\mathrm{~s}]\end{array}$ & \begin{tabular}{|c} 
構造物の総質量 \\
に対する TMD \\
の総質量の比
\end{tabular} \\
\hline \multirow{2}{*}{ F20-1-1 } & TMD_1d1, 2 & 39713 & 1191 & $0.630,0.718$ & 0.642 & \multirow{2}{*}{0.013} \\
\hline & TMD_4d1, 2 & 21444 & 643 & $0.350,0.399$ & 0.356 & \\
\hline \multirow{2}{*}{ F20-10-1 } & TMD_2d1, 2 & 45732 & 1372 & $0.330,0.376$ & 0.336 & \multirow{2}{*}{0.018} \\
\hline & TMD_4d1, 2 & 38279 & 1148 & $0.195,0.223$ & 0.199 & \\
\hline F20-100-1 & TMD_1d 1,2 & 49152 & 1475 & $0.261,0.298$ & 0.266 & 0.011 \\
\hline \multirow{2}{*}{ F20-1-10 } & TMD_1d1, 2 & 37147 & 1114 & $0.563,0.642$ & 0.574 & \multirow{2}{*}{0.016} \\
\hline & TMD_10q1 4 & 34560 & 518 & $0.202 \sim 0.258$ & 0.219 & \\
\hline \multirow{2}{*}{ F20-1-100 } & TMD_1d1, 2 & 37845 & 1135 & $0.527,0.601$ & 0.537 & \multirow{2}{*}{0.016} \\
\hline & TMD_10q1 4 & 33725 & 506 & $0.196 \sim 0.250$ & 0.213 & \\
\hline \multirow{3}{*}{ F30-1-1 } & TMD_1d1, 2 & 34943 & 1048 & $0.941,1.073$ & 0.958 & \multirow{3}{*}{0.021} \\
\hline & TMD_4q1 4 & 38883 & 583 & $0.420 \sim 0.537$ & 0.456 & \\
\hline & TMD_7q1 4 & 29827 & 447 & $0.310 \sim 0.396$ & 0.356 & \\
\hline \multirow{2}{*}{ F30-10-1 } & TMD_1d1, 2 & 45870 & 1376 & $0.423,0.483$ & 0.431 & \multirow{2}{*}{0.015} \\
\hline & TMD_3d1, 2 & 28672 & 860 & $0.264,0.301$ & 0.269 & \\
\hline \multirow{2}{*}{ F30-100-1 } & TMD_1d 1, 2 & 47600 & 1428 & $0.286,0.326$ & 0.291 & \multirow{2}{*}{0.018} \\
\hline & TMD_5d 1,2 & 41614 & 1248 & $0.128,0.145$ & 0.130 & \\
\hline \multirow{2}{*}{ F30-1-10 } & TMD_1d 1,2 & 33802 & 1014 & $0.805,0.918$ & 0.820 & \multirow{2}{*}{0.015} \\
\hline & TMD_5q1 4 & 39788 & 597 & $0.369 \sim 0.471$ & 0.400 & \\
\hline \multirow{2}{*}{ F30-1-100 } & TMD_1d 1,2 & 32735 & 982 & $0.698,0.796$ & 0.711 & \multirow{2}{*}{0.015} \\
\hline & TMD_5q1 4 & 38509 & 578 & $0.358 \sim 0.457$ & 0.388 & \\
\hline \multirow{3}{*}{ F40-1-1 } & TMD_1d1, 2 & 33237 & 997 & $1.012,1.154$ & 1.031 & \multirow{3}{*}{0.020} \\
\hline & TMD_3q1 4 & 40650 & 610 & $0.559 \sim 0.715$ & 0.607 & \\
\hline & TMD_7q1 4 & 26441 & 397 & $0.358 \sim 0.458$ & 0.388 & \\
\hline \multirow{2}{*}{ F40-10-1 } & TMD_1d 1,2 & 43772 & 1313 & $0.499,0.569$ & 0.508 & \multirow{2}{*}{0.014} \\
\hline & TMD_3d1, 2 & 27875 & 836 & $0.309,0.352$ & 0.315 & \\
\hline \multirow{2}{*}{ F40-100-1 } & TMD_1d 1,2 & 50298 & 1509 & $0.314,0.358$ & 0.320 & \multirow{2}{*}{0.018} \\
\hline & TMD_4d 1,2 & 39532 & 1186 & $0.158,0.180$ & 0.161 & \\
\hline \multirow{2}{*}{ F40-1-10 } & TMD_2d1, 2 & 31861 & 956 & $0.864,0.985$ & 0.880 & \multirow{2}{*}{0.014} \\
\hline & TMD_3q1 4 & 39581 & 594 & $0.494 \sim 0.631$ & 0.536 & \\
\hline \multirow{2}{*}{ F40-1-100 } & TMD_2d1, 2 & 32577 & 977 & $0.799,0.911$ & 0.814 & \multirow{2}{*}{0.014} \\
\hline & TMD_4q1 4 & 40569 & 609 & $0.443 \sim 0.566$ & 0.480 & \\
\hline
\end{tabular}

表 8 TMD の設計値

TMD名：TMD_3q1

制御対象とするモード次数 $匚 \mathrm{dn}$ : 二重 $\mathrm{TMD}$ の $\mathrm{n}$ 番目 $\mathrm{qn}:$ 四重 TMD $0 \mathrm{n}$ 番目

TMD の設置位置（制御対象モードの次数 : $<<\boldsymbol{\uparrow}<\boldsymbol{\uparrow}$ )

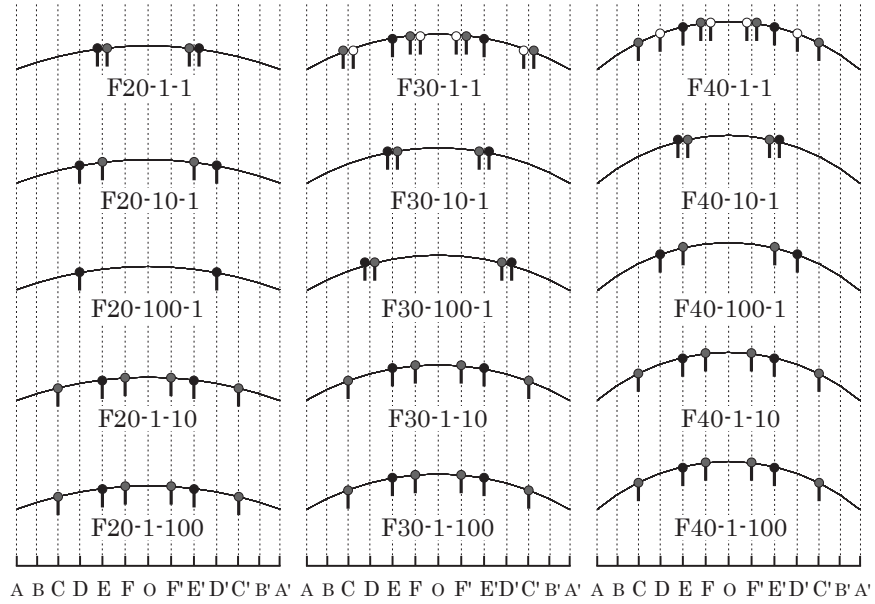

図 4 TMD の設置位置 
F40-1-1 は逆対称 1 波と逆対称 2 波のモードが卓越するため, 非制 振時の応答分布は卓越モードの形状により異なるものの, F30-100-1 以外のモデルでは $\mathrm{AOA}^{\prime}$ 上の最大応答加速度倍率を低減できてい る。F30-100-1 の最大鉛直応答加速度倍率がほとんど低減していな い要因は, 屋根構造がほとんど振動せず, 下部構造がスウェイする モードが卓越するため, 非制振時の最大鉛直応答倍率が小さくなり, TMD がほとんど振動せず振動を吸収することができなかったため である。最大水平応答加速度倍率の $\mathrm{A}, \mathrm{A}^{\prime}$ 点の応答が低減している ことから, 下部構造の水平応答も低隇できることがわかる。また, F20-1-1 の $\mathrm{C}, \mathrm{C}^{\prime}$ 点や F40-1-1 の $\mathrm{E}, \mathrm{E}^{\prime}$ 点の応答低減効果は低くなっ ている。そこで, 図 6(i) に示す F40-1-1 の E 点における時刻歴鉛直 応答加速度を見ると, 戝に示した時刻歴において概ね応答を低減す ることができているものの，○で囲んだ $18 \mathrm{~s}$ 付近での非制振時の応 答の急激な増大に対しては, 応答を低減できていないことがわかる。 これは, 構造物の応答が増大してから TMD の振動が大きくなるま でには時間を要するためである。一方, $\mathrm{F}$ 点では, 非制振時の最大 応答を発生する 3 周期前から TMD の振幅が増大しており, 振動が

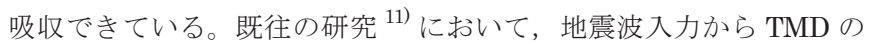
振動開始までには時間を要するため, 入力直後の応答低減効果が低 くなることが明らかとされているが, 入力中においても急激な応答 の増加に対しては応答をほとんど低減できないといえる。結果とし て, E 点のように非制振時の応答が急激に大きくなった直後に最大 応答が発生する場合には，最大応答の低減効果が低くなる。

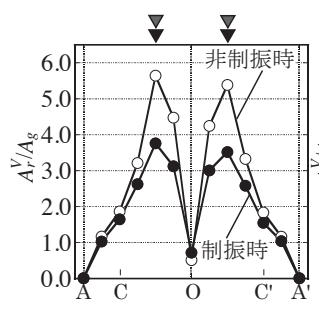

(a) F20-1-1

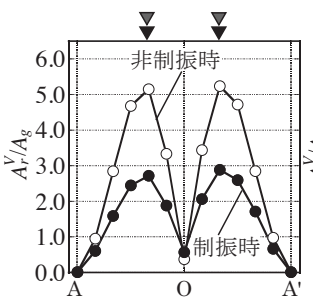

(d) F30-10-1
TMD の設置位置（制御対象モードの次数： $\mathbf{\nabla}<\boldsymbol{\nabla}<\nabla$ )

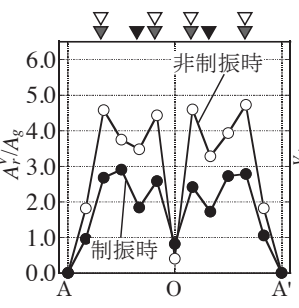

(b) F30-1-1

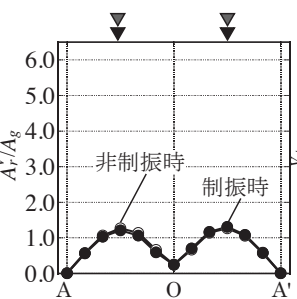

(e) F30-100-1

(i) 鉛直応答加速度

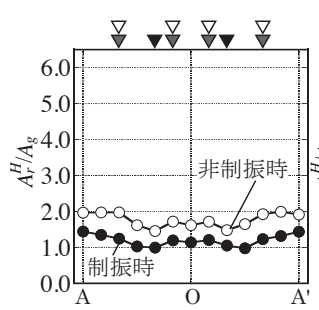

(a) F30-1-1

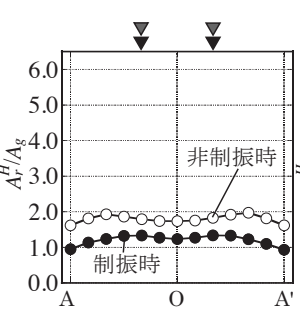

(b) F30-10-1

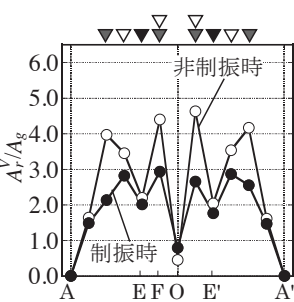

(c) F40-1-1 (ii) 水平応答加速度

(f) $\mathrm{F} 30-1-100$
5-2. 全制御対象モードにおける最大鉛直応答の割合の合計と鉛直 応答の二乗平均平方根の低減率の関係

図 7 に F30 の全制御対象モードにおける最大鉛直応答の割合の 合計と全節点の全解析ステップにおける鉛直応答の二乗值の総和の 平方根の低減率 (以降, 鉛直応答の二乗平均平方根の低減率と呼ぶ) の関係を示す。図中の $R_{A_{v}}^{\text {shell }}$ は鉛直応答加速度, $R_{D} e_{v}^{\text {shell }}$ は鉛直応答 変位の二乗平均平方根の低減率である。 $\mathrm{Re}_{A_{v}}^{\text {shell }}, \mathrm{Re}_{D_{v}}^{\text {shell }}$ は式 (12), (13) を用いて算出する。

$$
\begin{aligned}
& R e_{A_{V}}^{\text {shell }}=\sqrt{\sum_{j=1}^{N_{I}} \sum_{i=1}^{N_{I}}\left(A_{V i j}^{\text {shell_c}}\right)^{2} / \sum_{j=1}^{N_{J}} \sum_{i=1}^{N_{I}}\left(A_{V i j}^{\text {shell_unc }}\right)^{2}} \\
& R e_{D_{V}}^{\text {shell }}=\sqrt{\sum_{j=1}^{N_{J}} \sum_{i=1}^{N_{I}}\left(D_{V i j}^{\text {shell_c}}\right)^{2} / \sum_{j=1}^{N_{J}} \sum_{i=1}^{N_{I}}\left(D_{V i j}^{\text {shell_unc }}\right)^{2}}
\end{aligned}
$$

ここに, Av は鉛直応答加速度, D v は鉛直応答変位である。添字の shell_c は制振時, shell_unc は非制振時, i は解析ステップ数, N 1 は 全解析ステップ数である。

全てのモデルで鉛直応答の二乗平均平方根の低減率 $\mathrm{Re}_{\mathrm{A}_{v}}^{\text {shell }}, \mathrm{Re}_{\mathrm{D}}^{\text {shell }}$ が 1.0 未満になっており, 制御対象モードの自由振動特性によら ず構造物全体の応答が低減していることがわかる。ただし，F30-

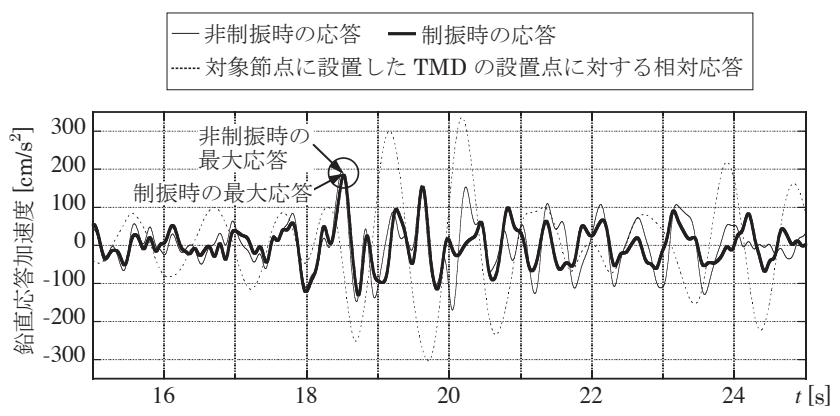

(i) $\mathrm{E}$ 点

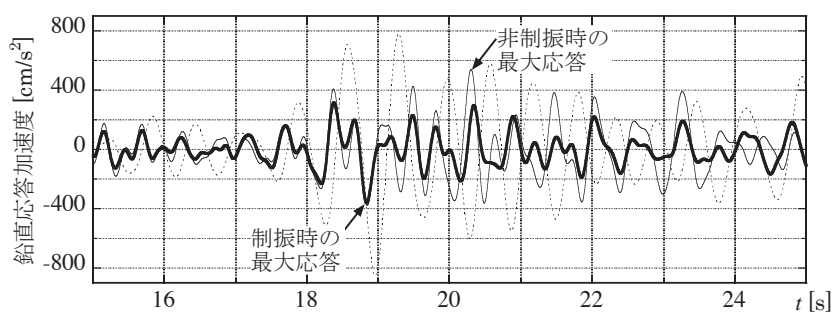

(ii) $\mathrm{F}$ 点

図 6 時刻歴鉛直応答加速度（F40-1-1, Hachinohe NS 模擬波入力）

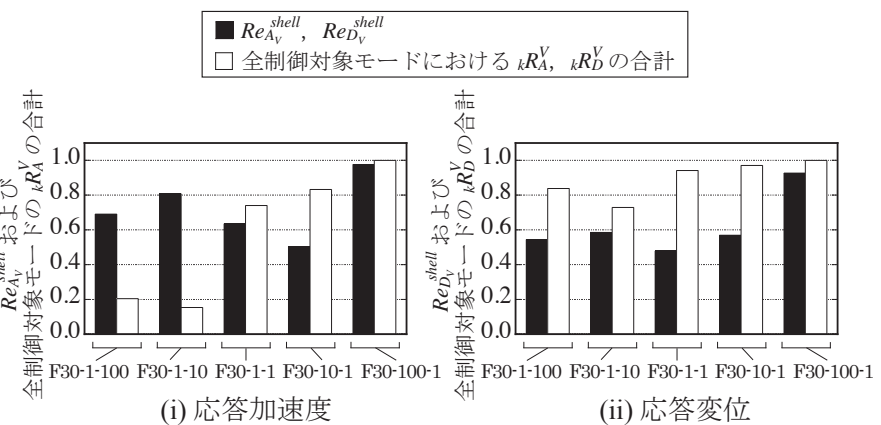

図 7 全制御対象モードにおける最大鉛直応答の割合の合計と 鉛直応答の二乗平均平方根の低減率の関係

(F30, Hachinohe NS 模擬波入力)

図 5 最大応答加速度倍率分布 (AOA' 上, Hachinohe NS 模擬波入力) 
100-1 の応答低減効果は低い。これは，前節で述べた要因によるも のである。以降では, F30-100-1 以外のモデルにおける応答低減効 果について分析する。

図 7(i) より, 応答加速度では F30-10-1 が最も応答低減効果が高い。 これは, F30-10-1 の全制御対象モードにおける最大鉛直応答加速 度の割合の合計が他のモデルに比べて大きいためである。一方, F30-1-100の全制御対象モードにおけるの合計は F30-1-1 に比べて 小さいが，F30-1-1 と同程度の応答低減率となっている。これは, F30-1-100 に設置した TMD が制御対象モードの固有周期より短周 期のモードが励起されたときに振動し, エネルギーを吸収したため であると考えられる。そこで, 図 8 に示すF30-1-100 における鉛 直応答加速度のフーリエ振幅スペクトルを見ると, 制御対象モード の固有周期である $T_{1}, T_{5}$ 以外の $T_{13}, T_{20}, T_{50}$ 付近で応答が低減し ていることがわかる。ここに, T はモードの固有周期, 添字の数字 はモード次数である。しかし, 文献 29) では, TMD の制御対象モー ドと, 固有周期が制御対象モードの 0.5 倍以下のモードとの連成は 無視できるとされているが，これは，TMDの制御対象モードの応 答の制振効果に着目したものであり, 制御対象モード以外のモード の応答に対する制振効果は分析されていない。そこで, 図 9 に示す 設置点に対する TMD の相対鉛直応答加速度のフーリエ振幅スペク トルを見ると, 制御対象としている $T_{1}, T_{5}$ 付近だけでなく, 制御 対象としていない $T_{13}, T_{20}, T_{50}$ 付近でも TMD が振動しているこ とがわかる。このことから, 制御対象モード以外のモードの固有周 期付近でもエネルギーを吸収しているといえる。また，TMD_1d1 の設置位置は 5 次, 50 次モードの腹, TMD_5q2 の設置位置は 1 次, 13 次， 20 次モードの腹となっている。そのため, TMD_1d1 では $T_{5}, T_{50}$ 付近, TMD_5q2 では $T_{1}, T_{13}, T_{20}$ 付近の応答が大きくなっ ている。また, TMD_5q2 の応答は $T_{1}$ 付近に比べて $T_{20}$ 付近の方が 大きい。このことから制御対象とするモードよりも長周期のモード
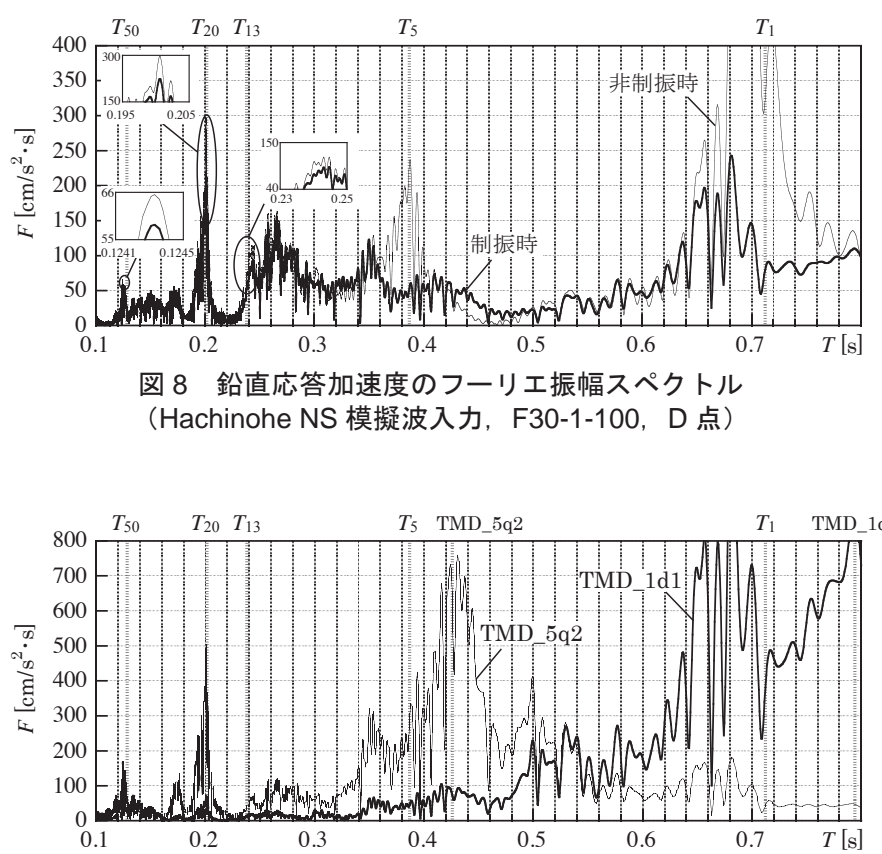

図 9 設置点に対するTMD の相対鉛直応答加速度の

フーリエ振幅スペクトル（Hachinohe NS 模擬波入力, F30-1-100)
に比べて, 短周期のモードの方がエネルギー吸収量が多いといえ る。図 7(ii) より, 応答変位においては, 全制御対象モードにおけ る最大鉛直応答変位の割合の合計がモデルによらず 0.7 以上となっ ており, 応答変位は $4 \sim 6$ 割程度に低減できている。上記の傾向は 半開角が $20,40 \mathrm{deg}$. の場合にも概ね同様である。

\section{5-3. 固有周期比 $R T$ と鉛直応答の二乗平均平方根の低減率の関係}

本節では, 固有周期比 RT と TMD による応答低減率の関係から, TMD による応答低減効果が高い固有周期比の範囲を検討する。固 有周期比 $R_{T}$ は, 屋根構造のみのモデルの逆対称 1 波モードの固有 周期 $T_{R}$ に対する屋根構造を剛と見なした場合の下部構造の等価固 有周期 $T_{\text {eq }}$ の比である。表 9 に対象構造物の固有周期比 RT を示寸。 本研究で対象とする構造物の $\mathrm{R}_{\mathrm{T}}$ は， $0.03 \sim 2.826$ の範囲にある。 図 10 に固有周期比 RT と屋根型円筒ラチスシェルの屋根面の鉛直 応答増幅率 $F_{R V}$ の関係を示す。 $F_{R V}$ は文献 22) に従い, 式 (14) を用 いて算出する。

$$
F_{R V}=A_{V \max } / C_{V} \theta A_{e q}
$$

ここに, Avmax は屋根面節点の鉛直応答加速度の最大值, $A_{e q}$ は屋根 構造を剛と見なした場合の下部構造の鉛直応答加速度, C V は半開 角に関する定数であり $\mathrm{C}_{V}=1.33, \theta$ の単位は $\mathrm{rad}$ である。

図中には文献 22) で提案された屋根型円筒ラチスシェルの鉛直応答 増幅率評価式である式 (15) も示す。

$$
F_{R V}= \begin{cases}3 & \left(0<R_{T} \leq 5 / 16\right) \\ \sqrt{5 / R_{T}}-1 & \left(5 / 16<R_{T} \leq 5\right) \\ 0 & \left(5<R_{T}\right)\end{cases}
$$

文献 22）と同様に, $\mathrm{R}_{\mathrm{T}}>5 / 16$ では $\mathrm{R}_{\mathrm{T}}$ が大きくなるにつれて $\mathrm{F}_{\mathrm{RV}}$ が 小さくなる。文献 21 ) では $R_{T}>1.85$ において屋根構造がほとんど

\begin{tabular}{|c|c|c|c|}
\hline モデル名 & $\begin{array}{c}\text { 屋根構造のみのモデルの } \\
\text { 逆対称 } 1 \text { 波モードの固有周期 } \\
\mathrm{T}_{\mathrm{R}}[\mathrm{s}] \\
\end{array}$ & $\begin{array}{c}\text { 屋根構造を剛と見なした場合の } \\
\text { 下部構造の等価固有周期 } \\
\mathrm{T}_{\mathrm{eq}}[\mathrm{s}] \\
\end{array}$ & $\begin{array}{c}\text { 固有周期比 } \\
\mathrm{R}_{\mathrm{T}}\end{array}$ \\
\hline F20-1-1 & 0.897 & 0.256 & 0.285 \\
\hline $\mathrm{F} 20-10-1$ & 0.275 & 0.256 & 0.930 \\
\hline F20-100-1 & 0.091 & 0.256 & 2.826 \\
\hline $\mathrm{F} 20-1-10$ & 0.897 & 0.081 & 0.091 \\
\hline F $20-1-100$ & 0.897 & 0.028 & 0.031 \\
\hline F30-1-1 & 1.171 & 0.263 & 0.224 \\
\hline F30-10-1 & 0.432 & 0.263 & 0.607 \\
\hline F30-100-1 & 0.154 & 0.263 & 1.709 \\
\hline F $30-1-10$ & 1.171 & 0.084 & 0.071 \\
\hline F30-1-100 & 1.171 & 0.029 & 0.025 \\
\hline F40-1-1 & 1.048 & 0.270 & 0.258 \\
\hline F $40-10-1$ & 0.488 & 0.270 & 0.554 \\
\hline F $40-100^{-1}$ & 0.201 & 0.270 & 1.346 \\
\hline $\mathrm{F} 40-1-10$ & 1.048 & 0.086 & 0.082 \\
\hline $\mathrm{F} 40-1-100$ & 1.048 & 0.031 & 0.030 \\
\hline
\end{tabular}

表 9 屋根構造と下部構造の固有周期比 $R_{T}$

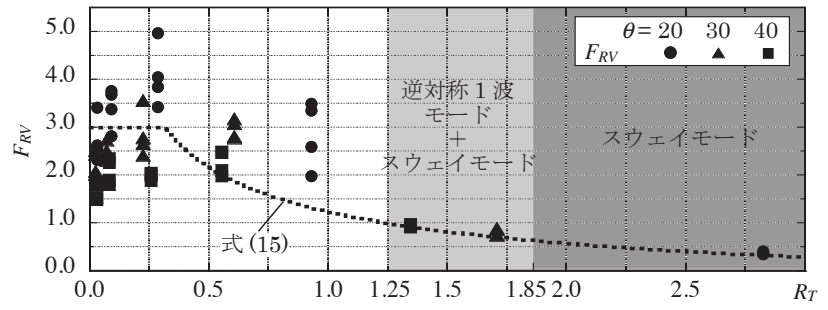

図 10 屋根型円筒ラチスシェルの鉛直応答増幅率 （告示に基づいた模擬地震波入力） 
振動せず，下部構造がスウェイするモードが卓越するとされてお り,この範囲においては $\mathrm{F}_{\mathrm{RV}}$ が非常に小さくなる。 $1.25<\mathrm{R}_{\mathrm{T}}<1.85$ では屋根構造が逆対称 1 波モードかつ下部構造がスウェイするモー ドが卓越し, 地震波によらず $F_{R V}$ が 1.0 以下となる。上記の $R_{T}$ と $F_{R V}$ の関係を踏まえ, 図 11 に示した固有周期比 $R_{T}$ と鉛直応答の二 乗平均平方根の低減率の関係を見ると， $\mathrm{R}_{\mathrm{T}}>1.25$ にあるモデルの ような $\mathrm{F}_{\mathrm{RV}}$ が小さい場合には, 応答加速度および応答変位の低減効 果が小さい。 $0.5<\mathrm{R}_{\mathrm{T}}<1.25$ の範囲にある $\mathrm{F}_{\mathrm{RV}}$ が大きいモデルでは, 応答加速度および応答変位を $4 \sim 7$ 割程度に低減可能であり, 他の モデルに比べて応答低減効果が高い。一方， $0.0<\mathrm{R}_{\top}<0.5$ にある モデルでは, 応答変位は $4 \sim 7$ 割程度に低減することができている ものの, 応答加速度は応答変位に比べて低減効果が低い。本研究で は, 有効質量比ではなく, より応答低減効果が高い応答変位の大き いモードを制御対象としており, 応答加速度は大きいが応答変位が 小さい高次モードは制御対象としていない。そのため, 高次モード に大きな有効質量比を有する $0.0<\mathrm{R}_{\mathrm{T}}<0.5$ にあるモデルの応答 加速度の低減効果が低くなっている。

以上より，3 章で提案した制御対象モードの選択方法に従い, 最 大鉛直応答変位の割合が $10 \%$ より大きいモードを制御した場合に は, $0.5<\mathrm{R}_{\mathrm{T}}<1.25$ の範囲にあるモデルにおいて, 応答加速度お よび応答変位の低減効果が他のモデルに比べて高くなるといえる。

\section{6. 並列多質点系による応答低減率の予測手法}

本章では，TMD を設置した屋根型円筒ラチスシェルを並列多質 点系でモデル化することにより，応答低減率を予測することを試み る。並列多質点系へのモデル化の方法は図 12 に示すように, 文献 18),19）で提案されている方法に従う。文献 18),19）では，全節点の 全解析ステップにおける鉛直応答の二乗值の総和の低減率をエネル ギー吸収率との関係から予測し，概称良い予測結果を得ることが可 能であることを確認した。本研究では, シェルモデルの最大鈆直応 答および鉛直応答の二乗平均平方根の低減率を 1 自由度系および並 列多質点系の応答から予測することを試夕る。応答低減率の予測手 順は以下の通りである。

1）図 12 のように，制御対象モードの 1 自由度系および並列多質 点系を作成する。

2）各モードの 1 自由度系, 並列多質点系の主系の時刻歴鉛直応 答をそれぞれ足し合わせる。

3-1）手順 2) で算出した 1 自由度系と並列多質点系における主系の 時刻歴鉛直応答加ら最大鉛直応答の低減率を得る。

3-2) 手順 2) で算出した 1 自由度系と並列多質点系における主系の 時刻歴鉛直応答から全解析ステップの鉛直応答の二乗值の総 和の平方根の低減率を得る。

図 13, 図 14 に 8 種類の地震波をそれぞれ入力したときのシェル モデルと並列多質点系の最大鋁直応答, 鉛直応答の二乗平均平方根 の低減率の対応を示す。シェルモデルと並列多質点系の応答低減率 は, 図 13 に示した最大鉛直応答の低減率に比べて, 図 14 に示し た鉛直応答の二乗平均平方根の低減率の方が良い対応を示してい る。 F *-10-1, F *-100-1（*は 20, 30，40）のシェルモデルと 並列多質点の応答低減率は, 半開角および地震波によらず他のモ デルに比べて対応が良い。これは制御対象モードにおける有効質
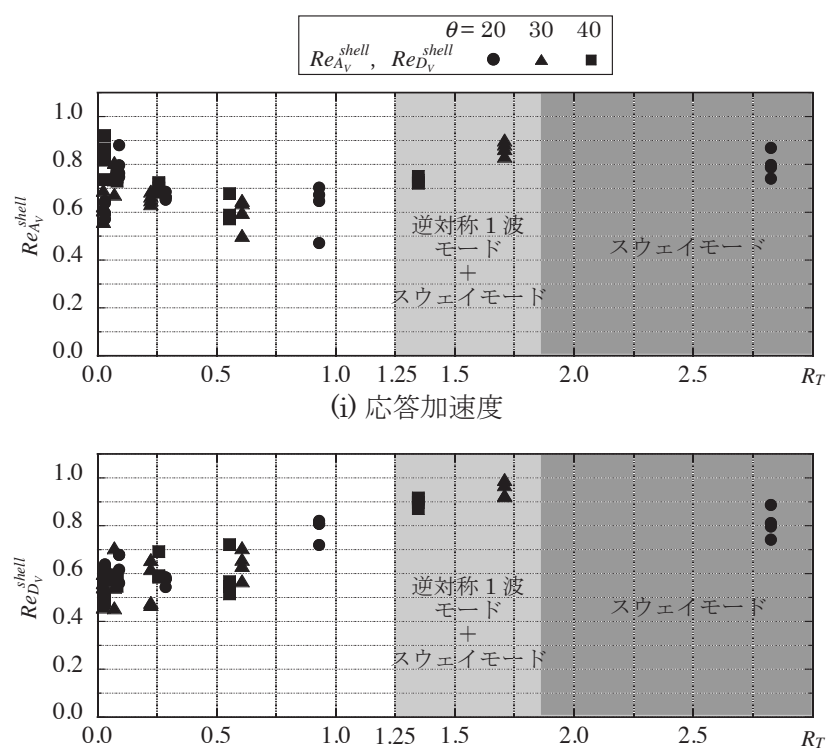

(ii) 応答変位

図 11 固有周期比 $R_{T}$ と鉛直応答の二乗平均平方根の低減率の関係 （告示に基づいた模擬地震波入力）

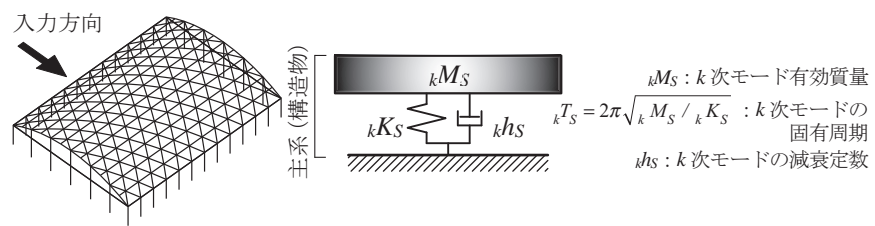

(i) シェルモデル

(ii) 1 自由度系

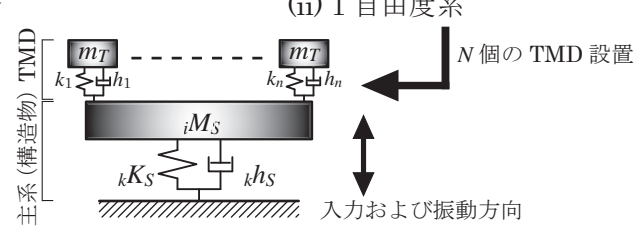

(iii) 並列多質点系

図 12 並列多質点系への置換

量比の合計が $90 \%$ 以上となっているため, シェルモデルの応答を 正確に再現できたことが要因である。一方で，F＊-1-10，F＊-1$100 （ * は 20 ， 30 ， 40 ）$ の制御対象モードにおける有効質量比の 合計は $20 \%$ 以下であり，地震波により低減率の対応が悪い場合が ある。そこで, 予測精度が悪い $\mathrm{F} *-1-10, \mathrm{~F} *-1-100 （ *$ は 20, 30，40）を対象として, 制御対象モード以外のモードも 1 自由度 系でモデル化し， 1 自由度系でモデル化したモードにおける有効質 量比の合計を $70 \%$ 以上とすることで, 応答低減率の予測精度の向 上を目指す。上記の方法に従い修正した $\triangle \boldsymbol{\Delta}$ で示寸応答低減率を見 ると，修正前に比べて対応が良いことがわかる。

以上より，1自由度系でモデル化したモードにおける有効質量比 の合計が大きい場合の, 最大鉛直応答および鉛直応答の二乗平均平 方根の低減率を予測可能であるといえる。

\section{7. 結}

本研究では, 屋根型円筒ラチスシェルを対象として, 水平方向入 力に対して励起される鉛直応答を TMD を用いて制振する場合に, 半開角および屋根構造と下部構造の固有周期比 $R_{T}$ を変えることに より変化する自由振動特性が TMD による応答低減効果に与える影 


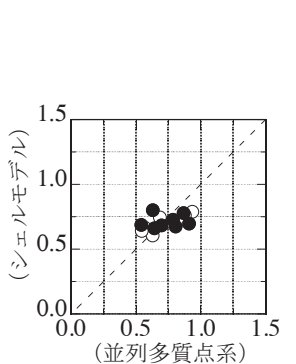

(a) F20-1-1

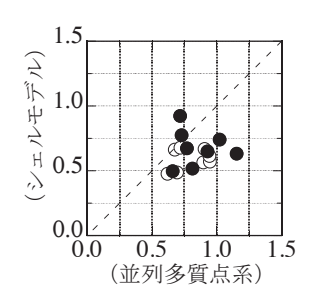

(a) F30-1-1

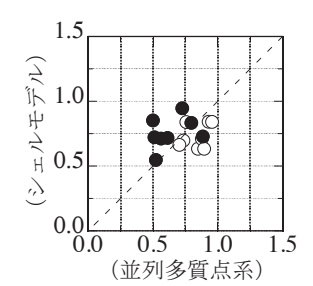

(a) F40-1-1

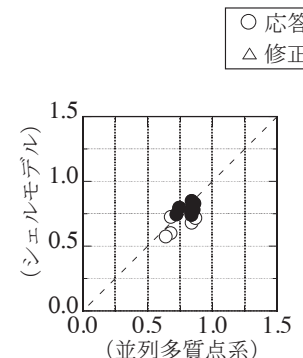

(b) F20-10-1

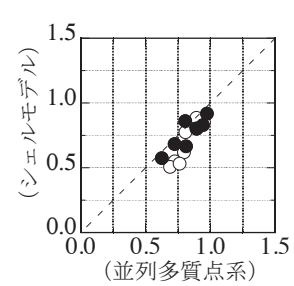

(b) F30-10-1

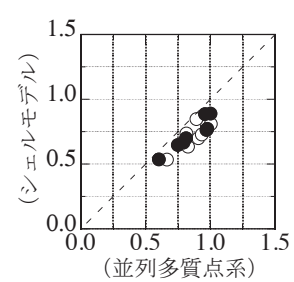

(b) F40-10-1

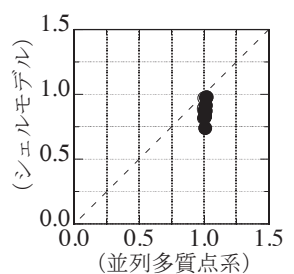

(c) F20-100-1

(i) F20

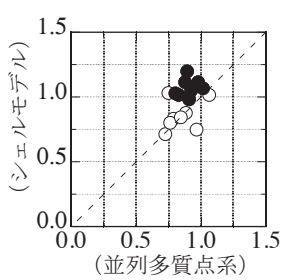

(c) F30-100-1

(ii) F30

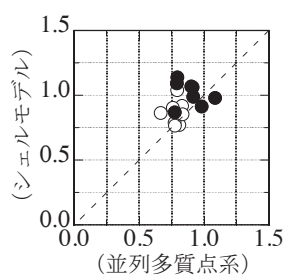

(c) F40-100-1

(iii) F40

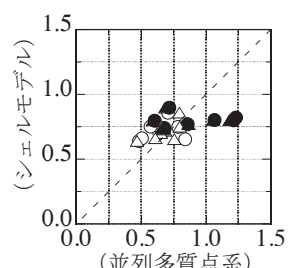

(d) F20-1-10

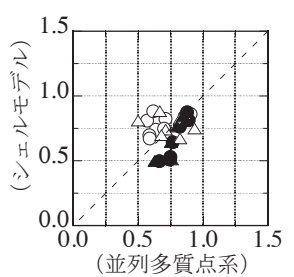

(d) F30-1-10

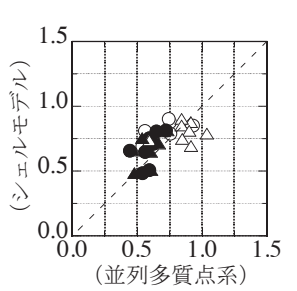

(d) F40-1-10

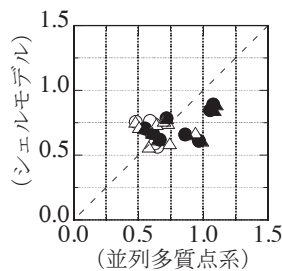

(e) F20-1-100

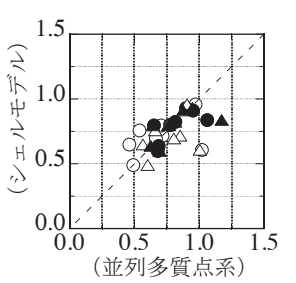

(e) F30-1-100

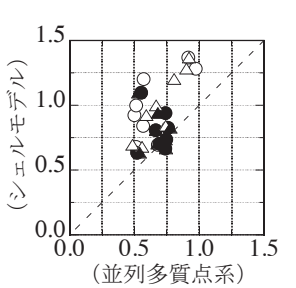

(e) F40-1-100

図 13 最大鉛直応答の低減率の対応

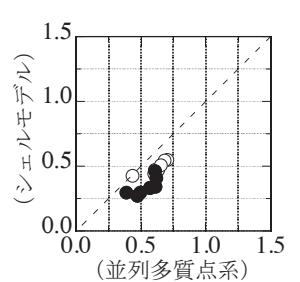

(a) F20-1-1

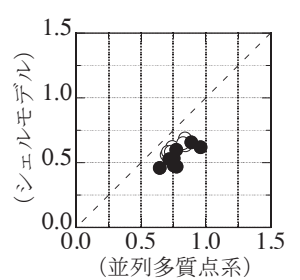

(a) F30-1-1

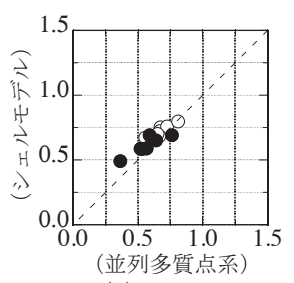

(a) F40-1-1

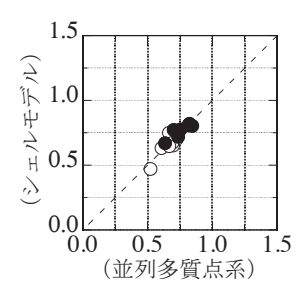

(b) F20-10-1

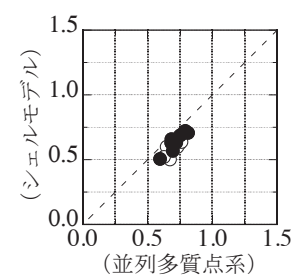

(b) F30-10-1

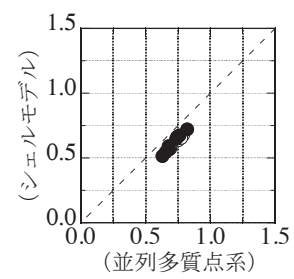

(b) F40-10-1

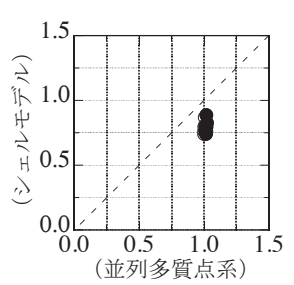

(c) F20-100-1

(i) F20

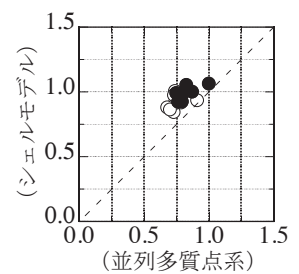

(c) F30-100-1

(ii) F30

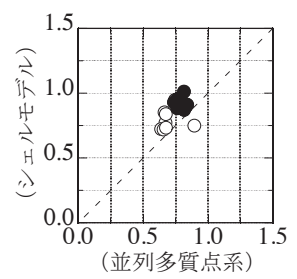

(c) F40-100-1

(iii) $\mathrm{F} 40$

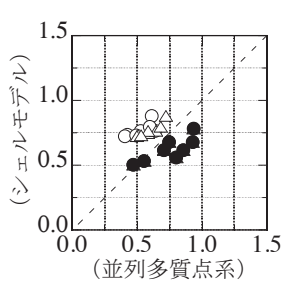

(d) F20-1-10

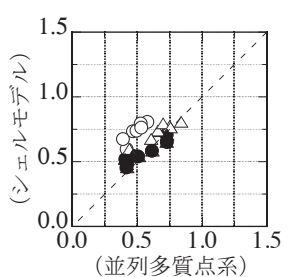

(d) F30-1-10

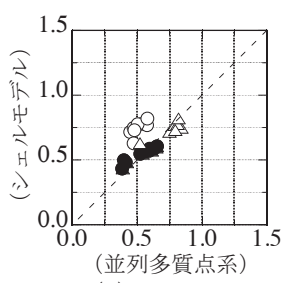

(d) F40-1-10

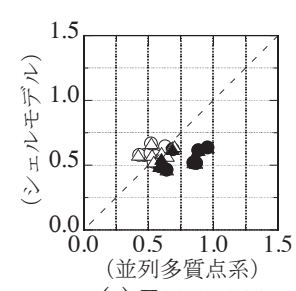

(e) F20-1-100

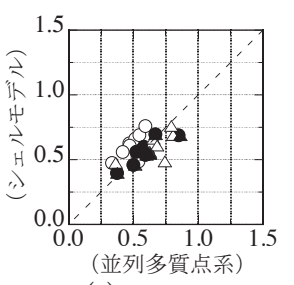

(e) F30-1-100

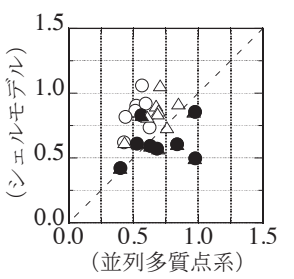

(e) F40-1-100

図 14 鉛直応答の二乗平均平方根の低減率の対応 
響について検討した。なお，TMDにより制御対象とするモードは， 地震動の周期特性を考慮した応答スペクトル解析を行い, 各モード の最大鉛直応答変位の割合を略算し, 最大鉛直応答変位の割合が大 きいモードとした。さらに，並列多質点系を用いて，TMDによる 応答低減率の評価を行った。以下に得られた知見を示す。

1) 多重 TMD の設置位置を, 文献 18),19) で構造物全体の応答の低 減が確認されている, 制御対象モードの全ての腹とすることで, 屋根型円筒ラチスシェルの自由振動特性に関わらず，応答を低 減可能である。

2) 応答スペクトル解析による略算值である全制御対象モードにお ける最大鉛直応答の割合の合計が大きいモデルでは応答低減効 果は高く，非制振時の鉛直応答が小さいモデルでは TMD がほと んど振動しないため応答低減効果は低い。

3） TMD の設置点において，制御対象とするモードの固有周期より 短周期のモードが励起される場合には, そのモードの応答も低 減する。

4) $0.5<R_{T}<1.25$ の範囲にあるモデルにおいて, 応答加速度およ び応答変位の低減効果が高くなる。また, 屋根面の鉛直応答増 幅率が小さい $\mathrm{R}_{\mathrm{T}}>1.25$ にあるモデルの応答はほとんど低減しな い。そのため, TMD を屋根型円筒ラチスシェルに適用する際に は, 屋根構造の固有周期のみでなく, 屋根構造と下部構造の固 有周期比を考慮する必要がある。

5）TMD を設置した屋根型円筒ラチスシェルを並列多質点系に置換 し，時刻歴応答解析を行うことで，構造物の自由振動特性によ らず最大鉛直応答および全節点の全解析ステップにおける鉛直 応答の二乗值の総和の平方根の低減率を予測することが可能で ある。ただし，制御対象モードにおける有効質量比の合計が小 さいモデルにおいて精度の良い予測結果を得るためには, 制御 対象モード以外のモードも 1 自由度系でモデル化し， 1 自由度系 でモデル化したモードにおける有効質量比の合計を大きくする 必要がある。

\section{参考文献}

1）日本建築学会編：空間構造の動的挙動と而震設計, 2006.3

2）薛 松濤, 大谷悟史, 長澤健二, 樋口喜司：大空間構造物における縦方 向 TMD に関する研究 その 1 模型製作及び実験詳細, 日本建築学会大 会学術講演梗概集，B-1 分冊，pp.913-914，2001.9

3）大谷悟史，薛 松濤，長澤健二，樋口喜司：大空間構造物における縦方 向 TMD に関する研究 その 2 実験結果及び結論, 日本建築学会大会学 術講演梗概集，B-1 分冊，pp.915-916，2001.9

4）吉中 進，川口健一：分散型 TMD による空間構造の振動制御に関する 一考察, 構造工学論文集, Vol.50B, pp.627-634, 2004.3

5）吉中 進，川口健一：MTMDによる大スパン建築構造の振動制御に関す る研究一アーチモデルを用いた振動台実験一, 日本建築学会構造系論文 集，第 621 号, pp.73-80, 2007.11

6) Den Hartog, J.P. : Mechanical Vibrations (4th ed.), Dover Publications, 1985.1

7）山口宏樹：構造振動・制御，共立出版株式会社，1996.5

8) 岩浪孝一, 背戸一登 : 2 個の複合動的吸振器の最適設計法とその効果, 日本機械学会論文集 $(\mathrm{C}$ 編 $), 50$ 巻 449 号, pp.44-52, 1984.1

9) 神谷圭二, 鎌形健太郎, 松本 進, 背戸一登: 多重動吸振器の最適設計法, 日本機械学会論文集 $(\mathrm{C}$ 編)， 62 巻 601 号，pp.22-27，1996.9

10) 津田勢太, 大崎 純 : 空間構造物の 2 方向応答制御のためのコンプライ アントメカニズムで構成されたマスダンパーのパラメータ最適化, 日本 建築学会構造系論文集，第 673 号，pp.379-387，2012.3
11）三松あずさ，熊谷知彦，小河利行，富本 淳 : 複数の TMD を用いたア 一千構造物の振動制御，構造工学論文集，Vol.58B，pp.489-495，2012.3

12) 楠 達明, 薛 松濤, 山田大彦: TMDによる単層ラチスドームの振動制 御，構造工学論文集，Vol.41B，pp.17-22，1995.3

13) 楠 達明, 山田大彦他：単層ラチスドームの地震応答と制震に関する基 礎的研究, その 1 乙 その 3 , 日本建築学会大会学術講演梗概集, B-1 分冊, pp.1901-1906, 1994.9

14）楠 達明，薛 松濤，山田大彦：単層ラチスドームの地震応答と制震に 関する基礎的研究，その 4 TMD の効果的な設定の検討，日本建築学会 大会学術講演梗概集, B-1 分冊, pp.621-622, 1995.8

15）吉中 進，川口健一：分散型 MTMDによる大スパン建築構造の振動制 御に関する研究—複数モ—ド制御のための MTMD バンド幅設定法一, 日 本建築学会構造系論文集，第 608 号，pp.77-84，2006.10

16) 吉中 進, 川口健一：分散型 MTMD による大スパン建築構造の振動制 御に関する研究一MTMD 分割とその制振効果に関する考察—, 日本建築 学会構造系論文集，第 73 巻，第 631 号，pp.1551-1559，2008.9

17) 吉中 進, 川口健一: 分散型 MTMD による大スパン建築構造の振動 制御に関する研究—MTMD の空間配置について一, 構造工学論文集, Vol.52B, pp.41-51, 2006.3

18）熊谷知彦, 下山拓也, 小河利行: 鉛直地震動を受ける屋根型円筒ラチスシェ ルの TMD による振動制御，構造工学論文集，Vol62B，pp.27-34，2016.3

19）熊谷知彦, 小河利行, 三松あずさ, 下山拓也, 松林哲平 : 複数の TMD を用いた屋根型円筒ラチスシェルの振動制御, 日本建築学会構造系論文 集，第 81 巻，第 725 号，pp.1103-1112，2016.7

20) 小河利行，中川美香，熊谷知彦：応答スペクトル解析法を用いた単層 ラチスドームの地震応答解析, 構造工学論文集, Vol49B, pp.291-296, 2003.3

21）竹内 徹, 小河利行, 中川美香, 熊谷知彦：応答スペクトル法による中 規模ラチスドームの地震応答評価, 日本建築学会構造系論文集, 第 579 号, pp.71-78, 2004.5

22) 竹内 徹, 小河利行, 山形智香, 熊谷知彦: 支持架構付き屋根型円筒 ラチスシェルの地震応答評価, 日本建築学会構造系論文集, 第 596 号, pp.57-64, 2005.10

23) 竹内 徹, 小河利行, 熊谷知彦, 中間明子, 佐藤英佑 : 支持架構付き ラチスドームにおける地震応答評価手法の適当範囲, 構造工学論文集, Vol52B, pp.53-61，2006.3

24）竹内 徹, 熊谷知彦，岡山俊介，小河利行：ライズの高い支持架構付き ラチスドームの地震応答評価, 日本建築学会構造系論文集, 第 73 巻, 第 629 号, pp.1119-1126, 2008.7

25) 竹内 徹, 渡辺 覚, 熊谷知彦, 小河利行 : ライズの高い支持架構付き 円筒ラチスシェルの地震応答評価, 日本建築学会構造系論文集, 第 76 巻, 第 666 号，pp.1515-1522，2011.8

26) 日本建築学会編：鋼構造設計規準 -許容応力度設計法-, 2005.9

27) 日本建築学会編：ラチスシェル屋根構造設計指針, 2016.11

28) 背戸一登 : 動吸振器とその応用，コロナ社， 2010.7

29) G.B.Warburton: Optimum Absorber Parameters for Minimizing Vibration Response, EARTHQUAKE ENGINEERING AND STRUCTURAL DYNAMICS, vol.9, pp.251-262, 1981 


\author{
Tomohiko KUMAGAI*, Takuya SHIMOYAMA** and Toshiyuki OGAWA*** \\ * Assoc. Prof., Dept. of Arch., School of Science and Technology, Meiji University, Dr. Eng. \\ ** JR East Design Corporation, M. Eng. (Former Grad. Student, Meiji University) \\ *** Prof. Emeritus, Tokyo Institute of Technology, Dr. Eng.
}

There are many examples of application of TMD. A high-rise building and a floor slab with large span in architecture field, a cable stayed bridge and a suspension bridge in civil engineering, for example. The response reduction effects in those examples are verified. TMD is fit for the vibration control of spatial structure because it is possible to install TMDs by a single supporting point. Therefore, there are many studies on spatial structure with TMD. The authors have verified the influences of the number and position of installed TMDs, the period and phase characteristics of earthquake motions and input direction of input wave on seismic response reduction effects. However, influence of free vibration characteristics of cylindrical lattice shell roofs on vibration control effects by plural TMDs have never been examined. From these backgrounds, the purpose of this study is investigation of seismic response reduction effects by plural TMDs for cylindrical lattice shell roofs which have different half open angles and ratios of natural period of supporting substructure to that of roof structure.

First, the selection method of controlled modes which are larger contribution to response displacement subjected to earthquake motion is proposed by response spectrum analysis. Next, the reduction effects of maximum responses and the sum of square of vertical responses of all nodes at all steps of analysis by plural TMDs for cylindrical lattice shell roofs which have different free vibration characteristics are examined. The relationships between the natural period ratios $\mathrm{R}_{T}$ of the natural period of equivalent single mass system to that of antisymmetrical 1 wave mode of roof structure and response reduction factors are investigated. Finally, the response estimation by parallel multi-mass system substituted for shell structure with TMDs is attempted.

From the numerical results, it is concluded as follows.

1) As plural TMDs are installed in all antinodes of controlled modes with larger contribution to the response displacements which are the locations that the reduction of responses for all nodes of structure is verified in references (18), (19), the responses reduce regardless of free vibration characteristics of cylindrical lattice shell roofs.

2) The response reduction effects by TMDs are higher as the sum of ratios of maximum vertical response of all controlled modes which are obtained from the response spectrum analysis is larger. On the other hand, the response reduction effects by TMDs are lower when the vertical response is smaller.

3) When the responses of the mode with natural period which is shorter than natural period of controlled mode occur in the positions for installing TMDs, the responses of the mode with natural period which is shorter than period of controlled mode reduce.

4) The reduction effects of response acceleration and response displacement are higher in the range of $0.5<R_{T}<1.25$. On the other hand, the responses hardly reduce in the range of $\mathrm{R}_{T}>1.25$. Therefore, when TMDs are applied to cylindrical lattice shell roofs, it is necessary to consider not only the natural period of roof structure but also the ratio of natural period of supporting substructure to that of roof structure.

5) When the sum of effective mass ratios of controlled modes is larger, the response reduction factors of cylindrical lattice shell roofs by installing the TMDs can be estimated by the parallel multi-mass systems substituted for shell structure with TMDs. 